\title{
An Analysis of Integrated Islamic School Al Ulum in Medan, Indonesia
}

\author{
M. ZahrinPiliang ${ }^{1}$, Prof. Dr. H. Haidar Putra Daulay ${ }^{2}$, Prof. Dr. H. Djakfar Siddik ${ }^{2}$ \\ ${ }^{1}$ Ph.D Student at State Islamic University of North Sumatra (UINSU), Medan, Indonesia \\ ${ }^{2}$ Postgraduate Lecturer at State Islamic University of North Sumatra (UINSU), Medan, Indonesia
}

\begin{abstract}
Historically, Integrated Islamic Schools in Islamic educational institutions emerged around the last decade of the 1980s. The idea is initiated by the da'wah activists at Public University campuses such as Institut Teknologi Bandung (ITB), Universitas Indonesia (UI), and other major universities, who are concerned about the condition of education in Indonesia.The integrated schools promote the principle of seamless education, namely education which is mutually sustainable and integrated: units of SD, SMP and SMA into a complete unity. Including the teachers, the staff, the laboratories, the classrooms, the buildings and other school resources are a unity. Integrated schools also try to provide the best service, especially the quality.In the implementation of integrated learning, in Integrated Islamic Schools Al-Ulum there still found inconsistencies teachers to integrate the Islamic values into their teaching subjects, for example, it is found in the lesson plan prepared by the teacher of geography class XI of SMA Integrated Al- Ulum. And so on lesson plan prepared by teachers of Chemical subject for Class $\mathrm{X}$ at the same school.
\end{abstract}

Keywords:Al Quran; integrated school; Islamic school; hadith

\section{INTRODUCTION}

In the midst of IPM conditions and globalization challenge of education, Islamic labeled national schools continue to search for their forms. Why is that so? Because one of the indicators to determine the IPM is the old number of the school. But the old number of the school is not enough; it has a parallel with the quality process of learning in the school. And one of the Muslims chosenforms of school of the middle-city is Integrated Islamic Schools that is the learning activity in public schools by integrating the modern science with the values or the teachings of Islam. The integration process of Islamic values is not only limited to the learning process as formally stated in the national curriculum, but also in the whole process of interaction in the school environment, from clothes that cover the aurat for male and female either for teachers or students, Duha prayer habituation, reading Al-Quran when starting and ending the learning, until the behavior and culture that reflect the Islamic school environment. Such school, by the managers is called an Integrated Islamic School.

In the context of public schools, the implementation of Integrated Islamic Schools can be traced through the policy of School Based Management (SBM), which in the early 2000s it was introduced by The Ministry of Education and Culture of Republic of Indonesia. In the MBS, the curriculum was designed based on competency or Competency Based Curriculum (CBC). Schools were given the freedom to develop and formulate local curriculum which still refer to nationalcurriculum. Next, this $\mathrm{CBC}$ was developed by the Government into a School-Baswed Curriculum (SBC) Year 2006. This SBC was valid until the presence of Curriculum 2013. However, the implementation of this Curriculum 2013 in school is in effect throughout Indonesia on this 2016-2017 Academic Year.The learning in Integrated Islamic Schools take a full day school, starting at 07:25 until 16:00 West Indonesian Time, or ended after the asharprayer. The implementation of Integrated Islamic Schools is intended to create to the Islamic generations who have the basics skills and reliability of science and modern technology, but with the foundation of personality and attitude firmly in the teachings of Islam, as well as have an authentic insight about the basics teachings of Islam.

The organizers of Integrated Islamic Schools implement an integrated school as a school that combines curriculum aspects and the learning between modern science and the teaching of Islamic values. Thus, Integrated Islamic Schools are not Islamic schools but public schools that are subject to The Ministry of Education and Culture of Republic of Indonesia in administrating education (school) from PAUD to SMA levels; Integrated Islamic Schoolsare not schools that combine common students with students whose special needs (disabilities) in the same school; Integrated Islamic Schoolsare the schoolsthat run a full day school, which in the learning processtryto instill the Islamic values at all learning either contained in the Learning Lesson Plan (RPP) or in the personal development program and extracurricular.

Historically, Integrated Islamic Schools in Islamic educational institutions emerged around the last decade of the 1980s, the idea was initiated by the $d a^{\prime} w a h$ activists at Public University campuses such as InstitutTeknologi Bandung (ITB), UniversitasIndonesia (UI), and other major universities, who are concerned 
about the condition of education in Indonesia. The campus activists play an important role in spreading the Islamic values as an ideology to the college students. The college students are the main target of this movement because it is believed that the college students would become the agents of social change, especially in the effort to do the Islanicscience and Indonesian Muslim community. Thus, it is expected that the dichotomous problem between modern science and the Islamic values can be minimized either in the educational environment or in the life activities of community, nationality and statehood.

Previously, it was known, if we talk about Islamic educational institutions it means pesantren or madrassas. In fact, long before the independence, Islamic educational institutions either founded by individuals like Adabiyah School (H. Abdullah Ahmad) in Padang, West Sumatra or by Islamic organizations such as MULO de Quran (Muhammadiyah) has made the "integration" of Islamic values into the learning in the schools they founded.Furthermore, the idea of the establishment of the Integrated Islamic School has continued, especially among the activists of Islamic education. In 2000, started from the birth of the 'top schools' term in private schools either managed by the general public or Islam labeled private schools, plus schools, and international pioneering schools. These schools are (ideally) trying to focus on improving the quality of the learning process (not on the quality of the students input) and the service quality to the students and other educational stakeholders (customer satisfactions).

\subsection{The Concept and Model of Integrated Schools}

\section{METHODOLOGY}

The implementation of an integrated school is in a complex, managed comprehensivelythecurriculum, the teaching, the teachers, the infrastructure and the management, or the evaluation so that the school becomes effective and qualified. Quality here means minimally meetsthe Education National Standards in every aspect so that it producesthe graduates who can compete with the graduates from other excellent schools. The integrated schools promote the principle of seamless education, namely education which is mutually sustainable and integrated: units of SD, SMP and SMA into a complete unity. Including the teachers, the staff, the laboratories, the classrooms, the buildings and other school resources are a unity. Integrated schools also try to provide the best service, especially the quality.

The management of such schools in the realm of Total Quality Management (TQM) in Education is meant to answer the demand for the products and/or services of education in order to be more qualified. The main focus of TQM in education sector is on improving the quality of education through the reorganization of educational practices. By doing so, it will create an image that in the integrated schools the integrated quality and services to the students with parents, and the community is the main concern of the institutions.By such organizing, there are several advantages including:

a. there is integration and the continuous process of learning between the implementation of learning among the units of SD, SMP, and SMA.

b. The facilities and infrastructure owned can be used together, so that their usage is more efficient and effective.

c. The teachers and staff can strengthen and adjust the content and the learning model so that the process becomes continuous or tied at the next level.

d. After graduation, the students can continue their education to the high school level at the same school without worrying about the adaptation anymore, so that te spirit in going to school and the developed competences are sustainable.

The other advantages of the integrated school are:

a. The management, the one stop based management among SD, SMP, and SMA is coordinated by a Director, or Head of Education (academic), but each unit has a principal who has autonomy in manage the school.

b. The curriculum, to integrate the national curriculum with the local curriculum (the characteristic of the school) which is continuous among units of SD, SMP, and SMA

c. The teaching and learning activities, that is to integrate the domains of cognitive, affective, and psychomotor fully in all activities. The planned learning is experiential learning.

d.The participation, that is to involve parents and external parties (the public) to participate as facilitators of education for learners. Parents are encouraged to be active providing motivation either individually to their children or their participation in the school program, and,

e. The school climate that is the social environment, relationships rules, behavior patterns and all the rules embodied in the framework of a onestop management. The pattern of environmental management is accordance with the laws of nature such as the arrangement of cleanliness, neatness, order, health, harmony, balance, and others. 


\subsection{Basic Principles of Integrated Learning}

The integrated learning must have an actual theme, close to the students, and has a relationship with everyday life. However, the theme must not be contrary to the existing curriculum; instead it must support the achievement of learning objectives.Below are the principles of integrated learning:

\section{a. Principles of Excavation Themes}

This principle is a key principle in the integrated learning.The overlap and linked themes become the main target in learning. Therefore the following conditions should be concerned:

1) It should not be too comprehensive, easy to use to integrate many subjects.

2) The theme should be meaningful; it is meant that the theme chosen to review can give provision for students to learn next.

3) The theme should be adjusted to the level of development of children's psychology

4) The developed theme should accommodate most of the child's interests.

5) The theme chosen should consider the important events that are authentic happened in the learning time span.

6) The theme chosen should consider the applicable curriculum and expectationsof the society (principle of relevancy).

7) The theme chosen should also consider the available learning resources.

\section{b. The principles of Integrated Learning Management}

In order the learning is optimal, the teachers must put themselves in the whole process. The teachers should become the facilitators and mediators for students in the learning process. With these principles, the teachers in the learning management:

1. Do not be single actors who dominate the conversation in learning process.

2. Giving the clear responsibilities of individuals and groups on any task that requires teamwork.

3. Accommodating the ideas that sometimes totally are not thought in the planning.

\section{c. Principles of Evaluation}

In any activity, the evaluation becomes one of focusesthat must be concerned. The result of a work can only be known if there is an evaluation. In integrated learning, evaluation requires positive steps as below:

1. Giving the students opportunitiesto do the self evaluationsor self assessmentsbesides other forms of evaluation.

2. The teachers should encourage the students to evaluate the learning acquisitions that have been achieved based on the criteria of success in achieving the objectives that will be achieved.

\section{d. The Principles of Reaction}

Due to the important nurturant effect for the students' realizing behaviors are not touched by the teachers in teaching learning activities, the teachers are required to plan and implement the learning thoroughly so that the learning objectives may be achieved. Therefore, teachers must immediately react to the actions of the students in all events by directing them to a full and meaningful thing.

\subsection{The Implementation of Integrated Learning in Schools}

The Government Regulation No. 19 Year 2005 on National Education Standards, which states that the Subjects Groups(KMP) are held holistically so that the learning of each subject groups (KMP) affect the students' understandingor comprehension. The implementation of holistic education is meant that the learning process in a single KMP is integrated in achieving the decidedcompetency standards.

The Education Development Center of Non-Formal and Informal (BP-PNFI) Region I has developed the Integrated Learning Model Packet ALevel II of Basic Competence Degree. One of subjects groups is Science and Technology that contained in the Package A includes BahasaIndonesia, Math, Science Studies, and Social Studies. The integration in that model is limited by three (3) subjects namely Mathematics, Science Studies, and Social Studies.To integrate all subjects is not easy, and it requires a analysis of the contents standard of the various subjects deeply. Here are the steps in preparing an integrated learning:

\section{a. Analyzing the Content Standards.}

In order to implement Competency Standardand Basic Competence as well as to meet the learning achievement, first a standard analysis of the contents is performed in each subject, and then the materials on other subjects of content standards are selected that can integrate with these subjects. In analyzing the contents standard, the competency mapping is performed that can be integrated from each Basic Competency of the subjects at one KMP. For example: Science Studies of Package A class VI. Competency Standards: Understanding the relationship between natural resources and the environment, technology, and society. While the Basic Competency: Explaining the relationship between natural resources and the environment. These

$\begin{array}{llr}\text { DOI: } 10.9790 / 0837-220406100107 & \text { www.iosrjournals.org } & 102 \mid \text { Page }\end{array}$


materials can be combined with the mathematics courses for sixth grade thatis to collect and to read the data. These materials can be combined with the social studies for fifth grade that is for basic competency to describe natural appearance in the district/city and province as well as its relationship with the diversity social and cultural.

\section{b. Designing the Teaching Materials}

In designing the teaching materials, it must comply with the standards of education content (either at the general education level or equity) that has been analyzed and mixed by integrating some subjects that have the same theme/overlapping. The teaching materials can be in the form of modules or other learning materials.

\section{c. Designing the Integrated Learning}

When making the lesson plans (in writing) as operational guidelines that will serve as guidelines for the teachers in learning activities through an integrated learning approach, the steps taken are:

1) Deciding a central theme of learning that will serve as a hook tool of learning.

2) Formulating the competency or learning objectives that must be achieved for the students.

3) Identifying the concepts that have good linkages properties found in the intra and inter subjects that will be integrated.

4) Formulating the learning scenarios that will be performed, and

5) Deciding an evaluation tool that will be done.

\section{d. Deciding the Concept}

The integrated learning much considers the students' needs in accordance with their development. Therefore, the activities given include being active in searching, exploring, and discovering the scientific concepts and science principles that are holistic, meaningful, and authentic so that the learners can apply the learning acquisitionto solve the real problems in daily life.

\section{a. The Integrated Learning Process}

\section{DISCUSSION}

At Integrated Islamic School Al-Ulum, the implementation of the education and learning takes a full day school starts at 7:30 to 16:00 am. This full day school is implementedin order to maximize the national education goals and the objectives of Integrated Islamic School Al-Ulum itself. In addition, a full day school is also intended to maximize the students to be more learning, studying, and socializing in the school environment.

The concept of integration which is the characteristic of Integrated Islamic Schools Al-Ulum, substantially is practiced in the learning process as follows:

1) The teaching learning activities begins with learning tahsin of Alquran which is carried out every day starting at 07:30 to 08:00, guided by each teacher;

2) Carrying out the implementation of the integrated learning in the learning process in each unit of SD, SMP, dan SMA starting at 8:00 to 13:30 pm as a continuation of learningtahsin ofAlquran in early learning.

3) The self development or extra-curricular activities after the entire national curriculum subjects are completedafter 13:30 pm.

As stated in Chapter II, in integrated learning, the process begins with (1) analyzing the content standards, (2) developing the teaching materials, (3) designing an integrated learning [which includes a) establishing a central theme, b) determining the competence or learning objectives, c) identifying the concepts that have relevance, d) formulating the learning scenarios, and, e) establishing the evaluation tools] and (4) applying the concept. Furthermore, the Learning Implementation Plan (RPP), preparing the earning materials/media land teaching aids, implementing the learning, and the finally carrying out the assessment.

The integrated learning as a concept can be interpreted as a learning approach that involves multiple subjects to provide a meaningful experience to the students. It is said to be meaningful because in the integrated learning, the students will understand the concepts they learn through direct experience and relate them to other concepts that they have already known.

Therefore, Integrated Islamic Schools Al-Ulum form a Curriculum Development Team on each unit (SD, SMP, dan SMA) which consists of Curriculum Development Team of Science studies group, social studes group and Islamic educational studies group. Each group prepares the terms of reference (syllabus)pfscience integration and the Islamic values that will be put into the Learning Implementation Plan (RPP) at each class meeting in accordance with the time allocation available. But, as stated above the CurriculumDevelopment Team do not produce the typical curriculum guide book, so thatthe implementation on the ground are left to the each teacher.Therefore, the integrated learning, as defined above, there has not been designed yet in this school as a learning approach that involves multiple subjects that provide the meaningful experiences to the students. The integrated learning meant here is the integration of Islamic values into the subjects that have been 
established in the national curriculum, in accordance with the level/grade and semester: including combining the educationof aqliyah, ruhiyah, andjasadiyah.In one of the lesson plans written by a teacher, for example, there is an integration of the Islamicvalues into the modern science subjects (physics). The RPP is prepared for XI-IPA (odd semester) classthat the basic competencies are: Analyzing rectilinear motion, circular motion, and a satellite dish by using vectors. The teachers of these subjects quote Q.S. 1-Anbiya ': 33:

It is He who created night and day and the sun and the moon, each of the two circulating inside the rotation line.

This verse then described in the relationship with a parabolic motion in a football game, circular motion in VCD disc, and so on, each of which has its own path.

In another RPP, on the subjects of Citizenship Education for class XII of odd semester, the teachers of this subjectwrite the Basic Competence as follows: Analyzing the system of government in many countries. The integration of Islamic values included Q.S. al-Nur: 55:

God had promised the people believe and work righteous deeds, that He will indeed make their ruling on the earth, as He made those before them in power.

It is explained that Islam uses'khilafah'as a keyword, not the word of sovereignty or the other. Therefore, the power holders and their usage must be in accordance with the norms and laws of God, that with them human becomeskhalifah(successor) of God. The power to regulate the earth, manage the country and the welfare of society and are promised to the whole faithful society, not a single mukminor a certain class. Each khalifahof God on earth is accordance with his individual capacity.However, in the explanation of the examples of governmentsthat ever existed began in classical antiquity (Plato) into this modern times, there is none of the reign of Islam which is shown by the teacher, so that the Al-quranverse cited is not followed by a more comprehensive explanation in relation to the Islamic government system, such as the beginning of the period of Prophet Muhammad PBUH in Medina, the Caliph al-Rashidun period, the caliphof Muawiyah, Abbasyiyah, Turki Usmani, and so on.

On the other hand, there is a lesson plan which does not present the integration of the Islamic values in the subjects taught, for example, on the subject of geography for class XI of odd semester. On Basic Competence it is written, Explainingthe definition of natural resources. For 90 minutes (the allocation time of 2 x 45 minutes), the teacher explains the core of learning, but there is absolutely no associated with the Islam values either rooted in the Al-Quran, Hadistand the views of Muslim scholars especially during the classical Islam about geography. Such examples reinforce the facts that has been pointed out that because of the absence of the typical curriculum guide book for the teachers guides, the integration process of Islam values into each subject (modern science) is not established fully and sustained.

Besides that the determination of Al-Quran verses, Hadistor the source of the history of civilization and other Islamic intellectualsthat made the references are not established by a formal decision by the institution of YayasanAmanahKaramah or Curriculum Development Team, or the Center for Quality Assurance in Perguruan Islam Al- UlumTerpadu. The quoting of Al-Quran verses or Hadith or the history of civilization and Islamic intellectuals by the teachers besides to be sought from various books that have integration, it is also based on the authority of the teachers to consider its relevance to the basic competencies of the subjects taught.

\section{b. Islamic Guidance}

The process of Islamic guidance in this school besides being integrated into the lesson plan in the classroom, it is also done outside the classroom; not only for students but for all school stakeholders such as teachers and education staff. For teachers and educational staff the Foundation organizes the Intensive Islamic Studies, which focused on the understanding and implementation of worship (mahdhah) as instructed by the AlQuran and Sunnahof RasulullahPBUH. Also in every month there are mental coaching that must be attended by all teachers and staff, where the speakers can come from internal source, but it can be from an external school.

For the students, as a consequence of Integrated Islamic School, Perguruan Islam Al- Ulum Terpadu applies the Full Day School (FDS). This step was taken in an effort to internalize the values of Islam to the students. With this model the students will follow the learning process in a shorter period of time, beginning at 7:25 to 16:00 pm. This relatively long time allows the school to teach all the materials contained in the curriculum, including the material in the local curriculum as learning Arabic, Alquran (tahfiz, tahsin), prayer together, Kultum, and others that related to the religious curriculum.

The primary focus of coaching at perguruan Al- Ulum Terpadu is tahfidz Alquran - which may be called as one of the peculiarities of this institution. Each student after graduating from Ulum must master the Al Qur'an memorization based on the level. Students of Class I and II of SD, for example, must memorize juz 30 , Class IIjuz 1, Class IV juz2, Class V juz 3 and Class VI juz 4, so that a student who completesthe education from class I - VI of SD in Perguruan Al- Ulum Terpadu will memorize five juz from 30 juz of Alquran. Also for students of Class VII-IX SMP must complete juz 5 to juz9 of Alquran. While the students of Class X - XI must master juz11, 12, 13, and for Class XII are added one more juz, namely juzXV. The ability to memorize a few juzof Al Qur'an is one indicator of the alumni profilesof Perguruan Islam Al- Ulum Terpadu Medan.. 
In the framework of this tahfidz Alquran program, specifically the school (by the Decree of the principal in each unit of SD, SMP, dan SMA forms the Development Center of Tahfidz Alquran (P2TQ).This Development Center is led by a teacher of Integrated Al- Ulum who can memorize 30 juz of Al-Quran. This P2TQ also designs the syllabus/curriculum and methods of TahfidzAl-Quran.

The process of Islamic coaching at school is not only conducted regularly in the classroom. In other word it is written in the RPP subjects, but also in the self development programs. The self development programs include arts programs such as nasyid, orkes gambus, dan angklung, photography, martial arts (merpati putih), marching band, and scouts.

In addition, there is also some coaching like practices to become mu'adzzin, imam, and even the exercisesto become FridayKhatib. According to the schedule specified in each grade in each unit, each student will take turn in giving the lectures on the topics given by the supervising teacher of Islamic lesson. At the foreword in their lectures, the students are required to use one of the foreign languages, Arabic or English.In the scouts program, particularly in relation to Tanda Kecakapan Khusus(Special Talent Mark) there are programs such as speech, Tahfidz (out of the P2TQ program), Malam Bina Iman dan Taqwa (MABIT), which include muhasabah, meditation, tahajjud, independence, and suggestion of consciousness. The MABIT program is applied to each unit of SD, SMP, dan SMA, in a series of Perkemahan Sabtu Minggu (PERSAMI) or Saturday Sunday Camp. Excluded in This PERSAMI program is for SD unit known as Perkemahan Satu Hari (PERSARI) or One Day Camp withouht staying by remembering their young age.

\section{c. Integration of Modern Science and Islamic Values}

The core of the emergence of Integrated Islamic Schools, one of them is how to integrate modern science and the Islamic values in learning in the school environment. At Perguruan Islam Al- Ulum Terpadu particularly in relation to preparing the lesson plans to be taught in the classroom, there is no guideline that becomes the educational guide in formulating the integration of Islamic valuesinto modern science, as in schools who are the members of t Jaringan Sekolah Islam Terpadu (JSIT) Indonesia, so that the formulation of Learning Implementation Plan (RPP) is entirely left to the teacher. It depends on the teachers' creativity in designing the integrated learning of Islamic values into modern science subjects. The teachers have limited in mastering the Islamic sciences, especially in understanding the substance of the verses of the Alqur'an, the Sunnah (Hadith), the history of civilization and Islamic intellectuals that are associated with modern science either in the scope of the natural sciences, mathematics, social studies, and humaniora. To counter that, the steps taken by the Foundation is to carry out activities such as training sessions for teachers on the integration of Islamic valuesin modern science.

Below is a form of integration of Islamic values to modern science in the subject of Chemistry for Class VIII of odd semester, taken from a teacher's RPP in Chemistry subjects.

\section{Learning Implementation Plan (RPP) Junior High School Level (SMP)}

\begin{tabular}{|c|c|c|c|}
\hline Class & Subject & $\begin{array}{r}\text { Basic Competence BSNP } \\
\text { National Curriculum }\end{array}$ & Integration of Islamic Values \\
\hline VIII & Chemistry & $\begin{array}{l}\text { 1. Explain the concept of } \\
\text { atoms, ions, and molecules }\end{array}$ & $\begin{array}{l}\text { The concerned quotes Q.S. Yunus: } 61 \\
\text { along with the translation. }\end{array}$ \\
\hline
\end{tabular}

As stated in Chapter II,the integration of Islamic values into modern science refers to the three patterns that have been developed in the Islamic world. First, a group who legitimizes the results of modern science by finding out the verses from Al-Quran, Sunnah and Islamic intellectual history of civilization, which are in accordance with the theory in science. This group considers modern science is universal, neutral and value-free. This group is represented by Maurice Bacaille and his students. This group is also known as the apologetics.

Second, a group who works with modern science, while trying to learn the history and philosophy of science in order to filter out the non Islamic elements and then performing the Islamization. When modern science is in the Islamic society, then the function is modified, so that it can be used for the interests and ideals of Islam. This group is called the Islamization of knowledge represented by Isma'il al-Faruqi and FazlurRahman Malik Razi.

Third, a group who believes the science of Islam and tries to build it to create a truly Islamic scienceswhich departs from the paradigm of Islamic science. This third group is represented by ZiauddinSardar and his colleagues Pervez Manzoor, GulzarHaider, and Munawar Ahmad Anees.

Having noted the contents of the typical curriculum of Perguruan Islam Al- UlumTerpadu who is effect into the learning implementation plan (PP), it is clear that the integration of Islamic values to modern science, followthe first pattern that is by finding out the Alquranbverses, Sunnah and Islamic intellectual history of 
civilization which are adapted to the basic competencies of the lessons to be taught. In the above example, a teacher of Chemistry, explains the concept of atoms, ions, and molecules, quotes Q.S. Yunus: 61 as follows:

You are not in a situation and did not read any of the Qur'an, or do any action without Our witnessing you while you do it. Did not escape the knowledge of God so much as zarrah (atoms) in the earth atapun in the sky. No more small and not (also) greater than that, but (all teratat) in a Clear Book (LawhMahfuz).

Here we have not seen the efforts towards the second pattern and the third pattern. This can be understandable, because the task of integrating Islamic values into modern science is not an easy job, and not too light. It is a heavy task that becomes the primary mission of PerguruanTinggi Islam, while the teachers have the tasks to apply them at the level of primary and secondary education. But the effort towards reducing the dichotomy between modern science and the teachings of Islam through education from the basic level as Sekolah Islam Terpadu Al- Alum did should be used as a major project in the implementation of Islamic education in a holistic manner.

\section{CONCLUSION}

In the implementation of integrated learning, in Integrated Islamic Schools Al-Ulumthere still found inconsistencies teachers to integrate the Islamic values into their teaching subjects, for example, it is found in the lesson plan prepared by the teacher of geography class XI of SMA Integrated Al- Ulum. And so onlesson plan prepared by teachers of Chemical subject for Class X at the same school. The Integrated Islamic Schools can be used as an alternative Islamic education, besides those who already exist, namely pesantrendanmadrasahbecause The Integrated Islamic Schools are not merely public schools, but the schools that integrate the Islamic values into each learning subjects, self-development programs, and extra-curricular programs.

\section{REFERENCES}

[1] Al QuranAhmadi, KhoiruIif, SofyanAmri, danTatikElisah. Strategi Pembelajaran Terpadu, Pengaruhnya Terhadap Konsep, Mekanisme, dan Proses Pembelajaran Sekolah Swasta dan Negeri. Jakarta: PrestasiPustaka, 2011.

[2] Al- Faruqi, Isma'ilRazi. IslamisasillmuPengetahuan. Bandung :Pustaka, 1984.

[3] Al- Attas, Syed Muhammad al-Naquib. Islam Dan Sekularisme.Bandung :Pustaka, 1981.

[4] Anshari, EndangSyaifuddin. Piagam Jakarta 22 Juni 1945.Bandung :Pustaka, 1983.

[5] Asari, Hasan. MenguakSejarah, Mencari 'Ibrah, RisalahSejarahSosial-Intelektual Muslim Klasik. Bandung :Citapustaka Media, 2006.

[6] Bakar, Osman, HierarkiIlmu, MembangunRangka-PikirIslamisasiIlmuMenurut Al-Farabi, Al-Ghazali, Quthb Al-Din Al-Syirazi, Bandung : PenerbitMizan, 1997

[7] Buchori, DidinSaefuddin. SejarahPolitik Islam.Jakarta :PustakaIntermasa, 2009.

[8] Daulay, Haidar Putra. Pendidikan Islam di Indonesia. Bandung :Citapustaka Media, 2001.

[9] Denzin, Norman K., dan Lincoln, Yvonna S. Handbook of Qualitative Research, (edisiBahasa Indonesia), Yogyakarta :PustakaPelajar, 2009

[10] DepartemenPendidikanNasional.Undang-UndangNomor 20 Tahun 2003 Tentang Sistem Pendidikan Nasional.Jakarta :Depdiknas, 2003.

[11] DepartemenPendidikanNasional.PeraturanPemerintahNomor 19 Tahun 2005 Tentang Standar Nasional Pendidikan. Jakarta. 2005

[12] Departemen Agama, DirektoratJenderalKelembagaan Agama Islam. Rekonstruksi Sejarah Pendidikan Islam di Indonesia. Jakarta: Departemen Agama RI, 2005

[13] Departemen Agama RI, SejarahPendidikan Islam di Indonesia. Jakarta: DirjenBinbaga, 1986

[14] Djaelani, Anton Timur. PeningkatanMutuPendidikandan Pembangunan Perguruan Agama. Jakarta: Dermaga, 1980.

[15] Drajat, Zakiah. IlmuPendidikan Islam.Jakarta: Bumi Aksara, 1992.

[16] Drake, Susan M. Menciptakan Kurikulum Terintegrasi Yang Berbasis Standar. Jakarta : PT Indeks, 2013.

[17] Fautanu, Idzam. FilsafatIlmu, Teori\&Aplikasi.Jakarta :Referensi, 2012.

[18] Fitri, AgusZainal. ManajemenKurikulumPendidikan Islam, Dari Normatif-Filosofis ke Praktis, Bandung : Alfabeta, 2013.

[19] Heriyanto, Husain. MenggaliNalarSaintifikPeradaban Islam.Jakarta :MizanPublika, 2011.

[20] Hilmy, Masdar. Pendidikan Islam danTradisillmiah.Malang :Madani, 2016.

[21] Hornby, AS. Oxford Advanced Learner's Dictionary, $8^{\text {th }}$ Edition, Oxford : Oxford University, 2013.

[22] Ilahi, MohamadTakdir. PendidikanInkulsif, Konsep\&Aplikasi.Yogyakarta :ArRuzz Media, 2013.

[23] Imron, Ali. BelajardanPembelajaran.Jakarta : PT DuniaPustaka Jaya, 1996.

[24] JaringanSekolah Islam Terpadu.StandarMutuKekhasanSekolah Islam Terpadu.Jakarta : JIST, 2014.

[25] Johnson B., Elaine. Contextual Teaching and Learning. California: Corwin Press, Inc., 2002

[26] Jujun Suriasumantri. Filsafat Ilmu, Sebuah Pengantar Populer, Sebuah Pengantar Populer. Jakarta : 
SinarHarapan, 1985

[27] Kartanegara, Mulyadhi. Mengislamkan Nalar, Sebuah Respons Terhadap Modernitas. Jakarta :Erlangga, 2007.

[28] Kuswanjono, Arqom. Integrasillmu\& Agama, Perspektif Filsafat Mulla Sadra. Yogyakarta :BadanPenerbitanFilsafat UGM. 2010.

[29] Madjid, Nurcholish. Islam : Doktrin dan Peradaban, Sebuah Telaah kritis tentang Masalah Keimanan, Kemanusiaan, dan Kemodernan, Jakarta, Yayasan Wakaf Paramadina,1992

[30] Maksum.Madrasah: Sejarah dan Perkembangan. Jakarta: Logos Wacana Ilmu, 1999

[31] Megawangi, Ratna, dkk. Pendidikan Holistik. Jakarta : 2005.

[32] Moelong, Lexy J. Metode Penelitian Kualitatif, eds revisi. Bandung : PT Remaja Rosda Karya, 2012

[33] Muhaimin, Rekonstruksi Pendidikan Islam.Jakarta : PT Raja Grafindo, 2009

[34] Mulyasa, H.E. Pengembangan dan Implementasi Kurikulum 2013.Bandung : PT. Remaj Rosdakarya, 2013

[35] Nasution. S. Kurikulum dan Pengajaran. Jakarta :BinaAksara, 1989

[36] Tim Pengembang MKDP Kurikulumdan Pembelajaran .Kurikulum dan Pembelajaran. Jakarta, 2012

[37] Trianto, Model Pembelajaran Terpadu, Konsep, Strategi, dan Implementasinya dalam Kurikulum Tingkat Satuan Pendidikan (KTSP).Jakarta :BumiAksara, 2013.

[38] Yamin, Martinis, Desain Baru Pembelajaran Konstruktivistik. Jakarta :Referensi, 2012.

[39] Zuhairini, dkk, Sejarah Pendidikan Islam, Proyek Pembinaan Parasarana dan Sarana PerguruanTinggi Agama/IAIN di Jakarta.Jakarta :Direktorat Jenderal Pembinaan Kelembagaan Agama Islam, 1986 